\title{
Nitric oxide preferentially inhibits nitrite oxidizing communities with high affinity for nitrite
}

\author{
Emilie N.P. Courtens ${ }^{\mathrm{a}, 1}$, Haydée De Clippeleir ${ }^{\mathrm{b}, 1}$, Siegfried E. Vlaeminck ${ }^{\mathrm{a}, *}$, \\ Robin Jordaens ${ }^{\mathrm{a}}$, Hongkeun Park ${ }^{\mathrm{b}}$, Kartik Chandran ${ }^{\mathrm{b}}$, Nico Boon ${ }^{\mathrm{a}}$ \\ a Laboratory of Microbial Ecology and Technology (LabMET), Ghent University, Coupure Links 653, 9000 Gent, Belgium \\ ${ }^{\mathrm{b}}$ Department of Earth and Environmental Engineering, Columbia University, 500 West 120th Street, New York, NY 10027, United States
}

\section{A R T I C L E I N F O}

\section{Article history:}

Received 16 July 2014

Received in revised form

21 November 2014

Accepted 24 November 2014

Available online 2 December 2014

\section{Keywords:}

Activated sludge

Energy-positive

Greenhouse gases

Nitrifier intermediates

Nitrous oxide

\begin{abstract}
A B S T R A C T
The prerequisite to the development success of the novel mainstream processes partial nitritation/anammox is the out-selection of nitrite oxidizing bacteria (NOB). A recent study suggested that this could be achieved through NO production by ammonium oxidizing bacteria under cyclic oxic-anoxic conditions. Indeed, it is known that among NOB, Nitrobacter species are reversibly inhibited by NO. However, the effect of NO on the activity of the NOB genus Nitrospira is not studied so far. Such an understanding is needed, since Nitrospira related NOB are mostly prevailing in sewage treatment plants. This study quantified the effect of NO on the nitratation activity of sludge types with different Nitrobacter/Nitrospira ratios. In an oxic bubbling column, a dosage of $4.4 \mathrm{mg} \mathrm{NO} \mathrm{L}^{-1} \mathrm{~d}^{-1}\left(\sim 2 \mu \mathrm{g} \mathrm{NO}-\mathrm{N} \mathrm{L}^{-1}\right.$ in liquid phase) inhibited the Nitrobacter dominated sludge with $24 \%$. For the Nitrospira dominated sludge types, the inhibition was strongly correlated with the nitrite half saturation constant $\left(K_{S}\right)$ ranging from $0 \%$ to $30-50 \%$ and $60-80 \%$ inhibition of the nitrite oxidation for $K_{s}$ of $0.72,0.36$ and $0.06 \mathrm{mg} \mathrm{NO}_{2}{ }^{-}-\mathrm{N} \mathrm{L}^{-1}$, respectively. This study showed that nitrifying communities with high affinity for nitrite and low specific nitrite oxidation rates (K-strategists) can be strongly inhibited by NO. The degree of inhibition could be confirmed in a set-up with NO dosage through an artificial alginate-based biofilm, ensuring a more direct contact between NO and the microorganisms.
\end{abstract}

(c) 2014 Elsevier B.V. All rights reserved.
Nitrite accumulation in activated sludge systems is detected when an imbalance in activity between aerobic ammonium oxidizing bacteria (AOB) and nitrite oxidizing bacteria (NOB) occurs. The differential in AOB and NOB rates can be obtained by for example operation close to washout sludge retention time of $A O B$ and cyclic oxic-anoxic conditions (Regmi et al., 2014; Wett et al., 2012) and is a prerequisite of the success of the novel mainstream processes partial nitritation/anammox (PN/A) (Kuai and Verstraete, 1998). However, an AOB/NOB activity differential (specifically, owing to relatively lower NOB activity) and thus nitrite accumulation often results in increased nitrous oxide $\left(\mathrm{N}_{2} \mathrm{O}\right)$ and nitric oxide (NO) emissions (Chandran et al., 2011; De Clippeleir et al., 2012; Kampschreur et al., 2009). The similarity in conditions allowing for an $\mathrm{AOB} / \mathrm{NOB}$ activity differential and $\mathrm{NO} / \mathrm{N}_{2} \mathrm{O}$ emissions is remarkable (De Clippeleir et al., 2013) and raised the question if the emissions are a mere result of the nitrite accumulation after

\footnotetext{
* Corresponding author. Tel.: +32 9 2645976; fax: +32 92646248.

E-mail address: Siegfried.Vlaeminck@UGent.be (S.E. Vlaeminck).

1 These authors contributed equally to this article.
}

establishment of NOB out-selection or if the emissions can play a role in the NOB out-selection itself.

From past studies, it is known that NO can suppress nitritedependent oxygen consumption rates in Nitrobacter species (Starkenburg et al., 2008) and therefore potentially can play a role in enhancing the $\mathrm{AOB} / \mathrm{NOB}$ activity differential in novel mainstream treatment processes omitting nitratation. However, the effect of NO on the activity of the NOB genus Nitrospira, which are mostly prevailing in sewage treatment plants (Daims et al., 2006), is not studied so far. Therefore, in this study the direct effect of NO on the NOB activity was studied in different types of nitrifying sludge (commercial nitrifying inoculum, conventional activated sludge, mainstream PN/A sludge and manure treatment sludge) with different Nitrobacter/Nitrospira ratios ranging between 61 and 0.01 (Table 1).

A clear distinction was observed between the Nitrobacterand Nitrospira-dominated types of sludge in terms of nitrite half saturation constants $\left(K_{S}\right)$. Nitrobacter-dominated sludge had higher 'apparent' nitrite half saturation constants compared to the Nitrospira-dominated types of sludge (Table 1) which correlated well with previous descriptions of Nitrobacter and Nitrospira 
Table 1

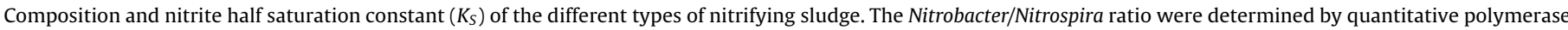

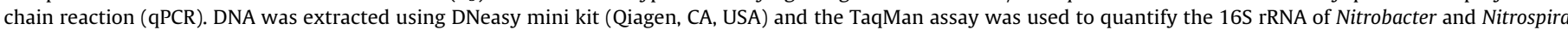

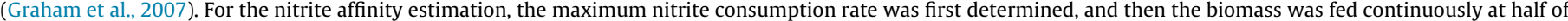
the maximum consumption rate. According to the Monod equation, the resultant stabilized nitrite level at this conversion rate was taken as the $K_{S}$.

\begin{tabular}{|c|c|c|c|c|}
\hline Sludge type & $\begin{array}{l}\text { Nitrobacter spp. (copies } \\
\mathrm{mg}^{-1} \text { VSS) }\end{array}$ & $\begin{array}{l}\text { Nitrospira spp. (copies } \\
\mathrm{mg}^{-1} \text { VSS) }\end{array}$ & $\begin{array}{l}\text { Ratio } \\
\text { Nitrobacter/Nitrospira (-) }\end{array}$ & $K_{S}$ nitrite $\left(\mathrm{mg} \mathrm{N} \mathrm{L}^{-1}\right)$ \\
\hline Commercial nitrifying inoculum & $3.6 \times 10^{5}$ & $5.9 \times 10^{3}$ & 60.88 & $1.50 \pm 0.09$ \\
\hline Conventional activated sludge process & $7.4 \times 10^{3}$ & $1.4 \times 10^{6}$ & 0.01 & $0.70 \pm 0.10$ \\
\hline Mainstream partial nitritation/anammox process & $8.5 \times 10^{5}$ & $1.9 \times 10^{6}$ & 0.45 & $0.36 \pm 0.02$ \\
\hline Manure nitrogen removal process & $5.9 \times 10^{5}$ & $1.3 \times 10^{6}$ & 0.45 & $0.059 \pm 0.007$ \\
\hline
\end{tabular}

enrichment culture experiments as $\mathrm{r}$ - and K-strategist, respectively (Blackburne et al., 2008). To test the effect of NO on the NOB activity in the nitrifying sludge, a NO/air mixture was bubbled through a water column in the presence of nitrite to allow for NO contact in aerobic conditions (dissolved oxygen $>4 \mathrm{mg} \mathrm{O}_{2} \mathrm{~L}^{-1}$ ). A dosage of $0.68 \mathrm{mg} \mathrm{NO} \mathrm{g}^{-1} \mathrm{VSS} \mathrm{d}^{-1}$ (100 ppmv NO gas) resulting in an approximate NO concentration in the liquid of $2 \mu \mathrm{g} \mathrm{N} \mathrm{L}^{-1}$ inhibited the Nitrobacter-dominated sludge (commercial nitrifying inoculum, $K_{S} 1.50 \mathrm{mg} \mathrm{NO} 2^{-}-\mathrm{NL}^{-1}$ ) by $24 \%$ (Fig. $1 \mathrm{~A}$ ). For the other types of sludge, the degree of inhibition was strongly correlated with the $K_{S}$ for nitrite ranging from $0 \%$ to $30-50 \%$ and $60-80 \%$ inhibition of the nitrite oxidation for $K_{S}$ of $0.70,0.36$ and $0.06 \mathrm{mg}$ $\mathrm{NO}_{2}{ }^{-}-\mathrm{NL}^{-1}$, respectively (Fig. $1 \mathrm{~A}$ ). The opposite trend could be observed in terms of specific NOB rates in the sludge types, showing lower inhibition in sludge types with higher specific nitrite oxidation rates normalized to NOB concentrations (Fig. 1B). Nitrifying communities dominated by Nitrospira-NOB, having a high affinity for nitrite and lower maximum specific growth rate (K-strategist) were strongly inhibited by NO.

The degree of inhibition in the bubbling columns could be confirmed in a set-up with NO dosage through an artificial alginatebased biofilm (Fig. 1A). In this set-up, the NO gas is forced to pass through the alginate-based biofilm ensuring a more direct contact between NO (100 ppmv NO gas) and the microorganisms, giving the low solubility of NO in water. Moreover, for the conventional activated sludge, where no NO inhibition could be observed in the oxic bubbling columns probably due to some diffusion limitations (mean floc size of $81 \mu \mathrm{m}$ compared with $16-33 \mu \mathrm{m}$ for the other sludge types), a significant NO inhibition was observed in the artificial biofilm test, showing the importance of the direct contact of NO with the NOB.

Previously studies showed a suppressing effect on nitritedependent oxygen consumption rates of Nitrobacter cultures for NO concentrations between 7 and $448 \mu \mathrm{g} \mathrm{N} \mathrm{L}^{-1}$ (Starkenburg et al., 2008). In our study, the estimated NO liquid concentration in all bubble column tests (based on a kLa $\mathrm{NO}_{\mathrm{NO}}$ of $706 \mathrm{~d}^{-1}$ ) was low $\left(2 \mu \mathrm{g} \mathrm{N} \mathrm{L}^{-1}\right)$ due to the low solubility of NO in water and this study therefore shows that even at very low NO concentrations in the liquid phase, significant effects on the NOB activity in the nitrifying sludge can be obtained. This indicates that the AOB/NOB activity differential needed in the novel mainstream technologies based on nitritation can potentially be enhanced by a certain level of in situ NO production, for instance by AOB. Indeed, increased AOB/NOB differential rates were observed at higher nitrite accumulation and subsequent higher NO emission in a mainstream $\mathrm{PN} / \mathrm{A}$ reactor (De Clippeleir et al., 2013). Because NO is produced in situ within the biofilm, floc or granule, the presence of anammox in a PN/A reactor will make it possible to take up the excess NO and thus not necessarily induce increased greenhouse gas emissions $\left(\mathrm{N}_{2} \mathrm{O}\right)$.

This study shows for the first time the direct effect of NO on NOB activity in nitrifying sludge and the dependency of the inhibition effect on the type of dominant NOB, characterized by the half saturation constant for nitrite, specific NOB rates and Nitrobacter/Nitrospira ratio. Further research is needed to elucidate the
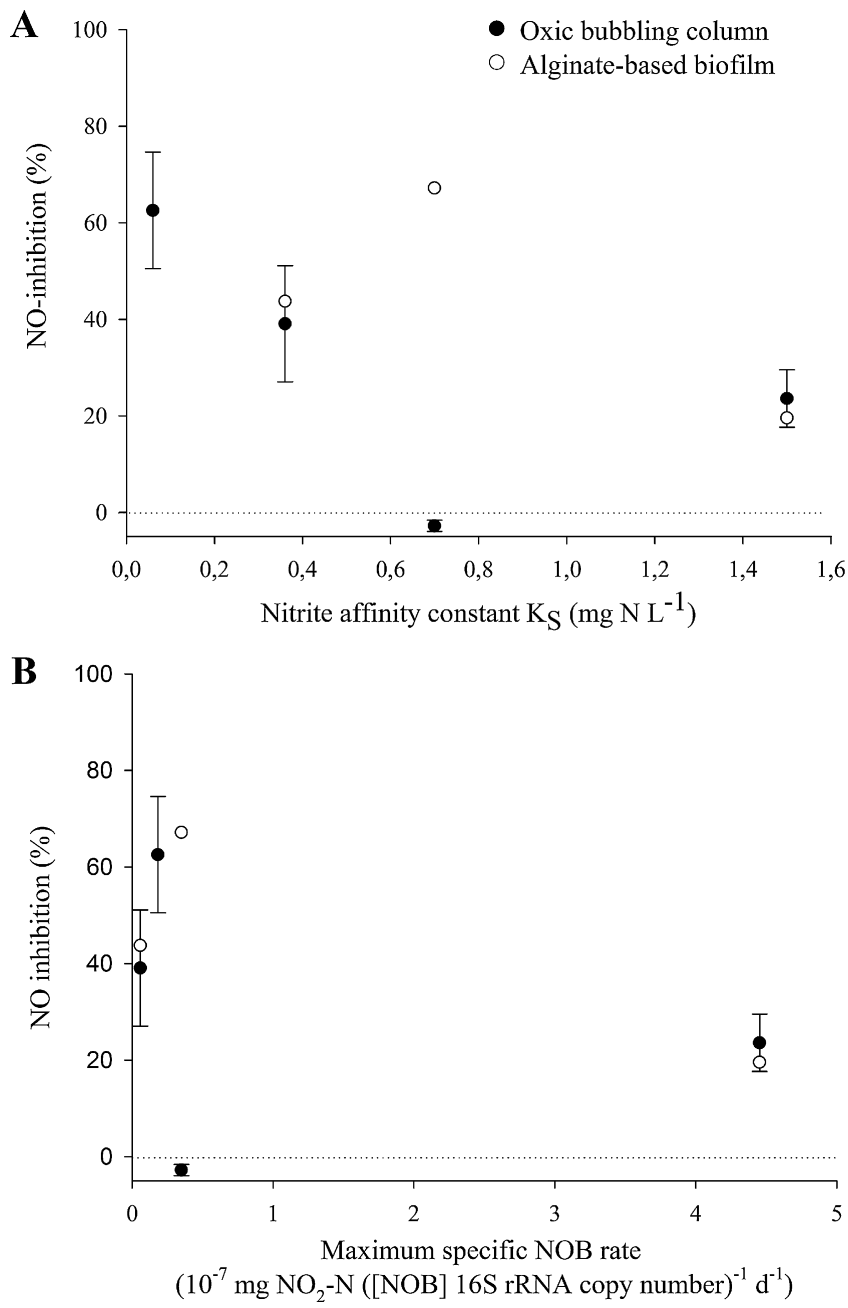

Fig. 1. Effect of nitric oxide (NO) on the NOB-activity of the different types of nitrifying sludge, presented in function of their $(\mathrm{A})$ nitrite half saturation constant $\left(K_{S}\right)$ and (B) maximum specific NOB rate. The NOB rates were determined by measuring nitrite consumption/nitrate production rates under non-limiting nitrite concentrations ( $>5 \mathrm{mg} \mathrm{N} \mathrm{L}^{-1}$ ) and compared to an identical control system without $\mathrm{NO}$ gas addition. Nitrite and nitrate concentrations were determined on a 761 Compact Ion Chromatograph (Metrohm, Switzerland) equipped with a conductivity detector. (•) NO-dosage of $4.4 \mathrm{mg} \mathrm{NOL}^{-1} \mathrm{~d}^{-1}$ (100 ppmv NO gas) in an oxic bubbling column (○) NO-dosage of $6.25 \mathrm{mg} \mathrm{NO} \mathrm{m}^{-2} \mathrm{~d}^{-1}$ through an alginate-based (1.5\%) biofilm $\left(153 \mathrm{~cm}^{2}\right)$, ensuring a more direct contact between NO and the micro-organisms. The community did not change in comparison with the bubbling column test as the biomass was not grown, but imbedded in the alginate biofilm just before the test and the duration of the test did not allow growth in the alginate. Both test set-ups were provided with a synthetic phosphate buffer solution ( $\mathrm{pH} 7.5$ ) containing 0.5-2.0 $\mathrm{g} \mathrm{PL}^{-1}\left(\mathrm{~K}_{2} \mathrm{HPO}_{4} / \mathrm{KH}_{2} \mathrm{PO}_{4}\right)$ and $10-150 \mathrm{mg} \mathrm{NO}_{2}-\mathrm{NL}^{-1}$ depending on the sludge activity. $\mathrm{NO}$ and $\mathrm{NO}_{X}$ were measured by chemiluminescence (Eco Physics CLD 77 AM, Switzerland) in inlet and off-gas samples of control experiments without biomass. The NO concentration in the off gas was always equal to the dosed NO concentration, indicating that no $\mathrm{NO}_{2}$ and/or nitrite was formed in this experimental set-up. 
mechanism of NO inhibition and the minimum level of NO needed in the system (within flocs/biofilms/granules) to enhance NOB outselection.

\section{Acknowledgements}

E.N.P.C. and S.E.V. were supported as doctoral candidate (Aspirant) and postdoctoral fellow, respectively, by the Research Foundation Flanders (FWO-Vlaanderen). H.D.C and K.C. were supported by the Water Environmental Research Foundation.

\section{References}

Blackburne, R., Yuan, Z., Keller, J., 2008. Partial nitrification to nitrite using low dissolved oxygen concentration as the main selection factor. Biodegradation 19, 303-312.

Chandran, K., Stein, L.Y., Klotz, M.G., van Loosdrecht, M.C.M., 2011. Nitrous oxide production by lithotrophic ammonia-oxidizing bacteria and implications for engineered nitrogen-removal systems. Biochem. Soc. Trans. 39, 1832-1837.

Daims, H., Maixner, F., Lücker, S., Stoecker, K., Hace, K., Wagner, M., 2006. Ecophysiology and niche differentiation of Nitrospira-like bacteria, the key nitrite oxidizers in wastewater treatment plants. Water Sci. Technol. 54, 21-27.
De Clippeleir, H., Vlaeminck, S.E., Wilde, F., Daeninck, K., Mosquera, M., Boeckx, P., Verstraete, W., Boon, N., 2013. One-stage partial nitritation/anammox at $15^{\circ} \mathrm{C}$ on pretreated sewage: feasibility demonstration at lab-scale. Appl. Microbiol. Biotechnol. 97, 10199-10210.

De Clippeleir, H., Weissenbacher, N., Schaubroeck, T., Hell, M., Boeckx, P., Boon, N., Wett, B., 2012. Mainstream Partial Nitritation/Anammox: Balancing Overal Sustainability With Energy Savings. WEFTEC, New Orleans/Los Angeles.

Graham, D.W., Knapp, C.W., Van Vleck, E.S., Bloor, K., Lane, T.B., Graham, C.E., 2007 Experimental demonstration of chaotic instability in biological nitrification. Isme J. 1, 385-393.

Kampschreur, M.J., Poldermans, R., Kleerebezem, R., van der Star, W.R., Haarhuis, R., Abma, W.R., Jetten, M.S., Jetten, M.S., van Loosdrecht, M.C., 2009. Emission of nitrous oxide and nitric oxide from a full-scale single-stage nitritation-anammox reactor. Water Sci. Technol. 60, 3211-3217.

Kuai, L., Verstraete, W., 1998. Ammonium removal by the oxygen-limited autotrophic nitrification-denitrification system. Appl. Environ. Microbiol. 64, 4500-4506.

Regmi, P., Miller, M.W., Holgate, B., Bunce, R., Park, H., Chandran, K., Wett, B., Murthy, S., Bott, C.B., 2014. Control of aeration, aerobic SRT and COD input for mainstream nitritation/denitritation. Water Res. 57, 162-171.

Starkenburg, S.R., Arp, D.J., Bottomley, P.J., 2008. Expression of a putative nitrite reductase and the reversible inhibition of nitrite-dependent respiration by nitric oxide in Nitrobacter winogradskyi Nb-255. Environ. Microbiol. 10, 3036-3042.

Wett, B., Podmirseg, S.M., Hell, M., Nyhuis, G., Bott, C., Murthy, S., 2012. Expanding DEMON Sidestream Deammonification Technology Towards Mainstream Application. SIDISA, Milano, Italy. 